\title{
Fields of Impact of Social Media on Youth - Methodological Implications
}

\author{
Stanistaw Juszczyk ${ }^{*}$
}

\begin{abstract}
Using social media Web sites is among the most common activities of today's children and adolescents. Such sites offer today's youth a portal for entertainment and communication, and have grown exponentially in recent years. Parents and teachers become aware of the nature of social media sites, thus they do not know that not all of them are healthy environments for children and adolescents. This field is important because pedagogists, psychologists and pediatrics need to understand how youth lives in a new, massive, and complex virtual universe, even as they carry on their lives in the real world. In the article I have presented a discussion of a few empirical research carried out by different authors to show various aspects of child and adolescent development in this virtual universe and to present the methodological implications of such types of studies.
\end{abstract}

Key words: Internet, social media, cyber-communication, youth, youth culture.

\section{Introduction}

Social media (e.g. Facebook, Blogger, Twitter, Flickr, YouTube, Second Life, and the like) as well as the places where they function are more complex in terms of the code, icon, symbol, construction and function. Social media also refer to the contemporary models of economic and social systems. They can be described as comprising all web-based and mobile networks which offer a free access with interactive connection. The unrestricted access (the free connectivity) allows a single user to browse, comment on and modernise the content for other users in different parts of the network and communicate with other users about this medium or the presented content.

The Internet is regarded rather as a new social environment, social network, space of global communication, educational and scientific space, or a space for leisure activities, such as playing computer games with other users. In the popular communication functions of the Internet such as e-mail, instant messaging, blogs, chat, and bulletin boards, adolescents are basically co-

* Stanisław Juszczyk, University of Silesia in Katowice, Katowice, Poland;

stanislaw.juszczyk@us.edu.pl 


\section{Acta Technologica Dubnicae \\ volume 5, 2015, issue 2}

constructing their own environments. Hence, cultural theories, such as those from linguistic anthropology or conversational analysis that emphasise coconstruction become very relevant (Duranti, 1977). Thus we see the Internet as a new cultural tool, or, better, as a cultural tool kit, because it is shared, norms are developed, and these norms, e.g. communication norms (Greenfield \& Subrahmanyam, 2003) are transmitted to new generations of users, even as the new users, greater access, and technological innovation create new norms. The Internet is a tool kit because it is an infinite series of applications, each with its own use.

\section{Discussion}

The impact of cyber-communication on today's youth

Cyber-communication (Juszczyk, 2013) influences, among others, in the personal domain, because it offers opportunities for valued learning, responsibility, and independence. Students can learn to manage time and resources effectively, master the art of accessing and processing skills gained in a meaningful context, and communicate this information clearly to the intended audience. Integrating the Internet with communication allows students to share personal perspectives, knowledge, experiences, and structure discussions for debate (Wakefield \& Rice, 2008).

The negative side of cyber-communication is the access to personal information, the user can find out where someone lives, a phone number, even directions to someone's house. Since, it is becoming increasingly hard to protect children from unsafe access to their personal information. Research carried out in the USA reveals that one in five youth, ages 10 to 17 , received unwanted sexual advances online (Olsen, 2006).

Communication through the Internet influences also in the social domain. Youth are actively using the Internet as an important form of social interaction (Brignall \& Valey, 2005). Social media sites such Facebook and My Space offer multiple daily opportunities for connecting with friends, classmates, and people with shared interests. Social circle is not limited to geographical locations, since young people geographically remote, disabled, or housebound due to illness may find online chat (social media) an important form of communication (Fleming \& Rickwood, 2004). This type of communication helps children who might not otherwise be confident to communicate to do so quite well over the Internet. Due to increased use of cyber-communication, a feeling of being autonomous also exists. However, there is less direct human contact, thus social isolation for adolescents and the impact on family relations is a concern (Littlefield, 2004). Social media sites allow teens to accomplish online many of the tasks that are important to them offline: staying connected with friends, making new friends, sharing pictures and exchanging ideas. Social media participation can also offer adolescents deeper benefits that extend into their view of self, community, and 


\section{Acta Technologica Dubnicae \\ volume 5, 2015, issue 2}

the world (Ito, Horst, \& Bittani, 2007). Social media sites cause growth of different ideas from the creation of blogs, podcasts, videos, and games, and foster one's individual identity and unique social skills (Boyd, 2008).

There is increasing freedom to harass and use put-downs because there are no repercussions personally. Because of their limited capacity for self-regulation and susceptibility to peer pressure, children and adolescents are at some risk as they navigate and experiment with social media. This creates cyber-bullying (Patchin \& Hinduja, 2006; Waligóra-Huk, 2012), cyber-stalking, cyberharassment conversations, clinic-forming, and sexual experimentation or "flaming" a public personal attack, where people demonstrate verbal aggression. Other observed differences include the open display of group norm violations such racism, sexism (sexting) (Lenhart, 2009), and homophobia (Brignall \& Valey, 2005). Other problems that merit awareness include Internet addiction and concurrent sleep deprivation (Christakis \& Moreno, 2009).

Influences in the emotional domain realized in issues related to anything from abuse to self-help. Many students access health resources like suicide hotlines, support groups, information on medical conditions, and contact with appropriate organizations. This interaction helps to give them a support system outside of their immediate environment to assist in dealing with emotional issues (Lenhart, Rainie \& Lewis, 2001). On the negative side, this ability to find resources regarding the emotional domain can be harmful. There are hemlock (suicide) societies online. There is information on how to build bombs, self-mutilate, be sexually active, participate in drug use, and many other illegal and illicit activities.

Researchers have proposed a new phenomenon called "Facebook depression", defined as depression that develops when preteens and teens spend a great deal of time on social media sites, such Facebook, and then begin to exhibit classic symptoms of depression (Selfhoud, Branje, Delsing, ter Bogt, \& Meeu, 2009). Acceptance by and contact with peers is an important element of adolescent life. The intensity of the on-line world is thought to be a factor that may trigger depression in some adolescents. As with offline depression, preadolescents and adolescents who suffer from Facebook depression are at risk for social isolation and sometimes turn to risky Internet sites and blogs for "help" that may promote substance abuse, unsafe sexual practices, or aggressive or self-destructive behaviours.

In such situations we can see in the USA a big role of paediatricians. They are in a unique position to educate families about both the complexities of the digital world and the challenging social and health issues that youth experience online by encouraging families to face the core issues of bullying, popularity and status, depression and social anxiety, risk-taking, and sexual development (O'Keeffe \& Clarke-Pearson, 2011). 


\section{Acta Technologica Dubnicae \\ volume 5, 2015, issue 2}

\section{Methodology of research of the social media impact}

Internet research involves locating the subject of the studies as well as the scope/area of the quality discussion and reasoning. Therefore, we can conduct research in which: (a) the Internet is the only research area, (b) the Internet becomes a research tool only or (c) research with the help of networks which refer to the phenomena occurring in different proportions both off-line and online (where the on-user is an active user and the off-user is an absent user).

Very interesting field research is conducted in the existing Internet environment in real time (i.e. on-line), while a researcher operates on the same terms as other network users, which means, for example, that he is a legitimate user of forums, not a guest. Thus, virtual ethnography, as a new and more often used method of empirical studies, is not research which only exploits the Internet as a platform for communication purposes such as conducting group or individual interviews on-line (Juszczyk, 2014). Since, we can see the Internet as a source of new methods for diagnostic research, as well as new research environment that requires the development of new methodologies. As a source of new methods, applications for public communication, represented by chat rooms (Selfhoud, Branje, Delsing, ter Bogt, \& Meeu, 2001) and bulletin boards (Greenfield \& Yan, 2006), provide a locus for observing peer interaction that is usually hidden from the view of adults in general and researchers in particular.

These new research sites require the development of new methodology. To utilize new sites, such as chat rooms, bulletin boards, and forums of discussion, with their unique virtual characteristics, we need to develop new techniques for collecting and analysing data. On a concrete level, this involves learning, how, technically, to take data from the Internet. On a mode conceptual and abstract level, this involves methods for analysing data on the cultural level (Mesch, 2009) - for analysing a communication environment where multiple interactions in shifting and overlapping groups render the individual as a unit analysis useless for certain purposes (Greenfield \& Subrahmanyam).

In this situation, every participant has a dual role - as an individual who may be affected by the social environment and as a participant whose interaction with others is co-constructing, that is, creating the same social environment. K. Subrahmanyam and his co-workers address this duality and methodological problem by shifting their focus of attention and their units of analysis to utilizing the individual - represented by a distinctive screen name - as a unit of analysis. The dynamic, complex, and gigantic Internet challenges researchers to develop methods for analysing massive amounts of online data quickly, effectively, and efficiently (Subrahmanyam, Kraut, Greenfield, \& Gross, 2000; Zillmann \& Bryant, 2002).

In conclusion, the Internet is more exciting and challenging as a research environment than earlier media because it is a complex virtual social and physical world that children and adolescents participate in and co-construct, rather than something that is merely watched (TV) or merely used (PC). It 


\section{Acta Technologica Dubnicae \\ volume 5, 2015, issue 2}

becomes a complex virtual universe behind a small screen on which developmental issues play out in old and new ways, offering new views into the thoughts, feelings, and behaviours of children and adolescents. This universe will continue to expand as Web-connected cell phones and other new Internet applications emerge. Thus, existing theoretical models, research programmes, and methodological techniques in pedagogy are both challenges and stimulated by interactions between youth and the Internet. This is an important and healthy sign of a new and growing area of research (Greenfield \& Yan, 2006; Gross, 2004).

\section{Conclusions}

The global network is becoming more and more a space of our lives and everyday functioning of not only the youth but also adults and elderly people. We use it for the purposes of our work, education, to search for information, communicate, interact with others and have contact with popular culture. Hence, on the Internet, we can observe many phenomena and processes reflecting the objective reality, which however occur in different ways and determine other variables.

Cyber-communication may change many aspects of our lives - private, social, cultural, economic, and intellectual. However, with proper instruction, guidance, and supervision, there is the potential for the impact of positive, personal growth. It is important to teach and model for our youth how and why to get "unplugged". In this age of ever increasing electronic usage, from cellular phones to computers to iPods to video games, it is vital to bring back human social interaction. Balancing the "virtual" world with the "real" world can be the greatest gift of all.

\section{References}

Boyd, D. (2007). Why youth (heart) social network sites: the role of networked publics in teenage social life. In D. Buckingham (Ed.), MacArthur Foundation Series on Digital learning Youth, Identity, and Digital Media Volume. Cambridge: MIT Press.

Boyd, D. (2008). Taken Out Context: American Teen Sociality in Networked Publics. Berkeley, CA: University of California.

Brignall, T. W., \& Valey, T. V. (2005). The impact of Internet communication on social interaction. Sociological Spectrum, 25, 335-348.

Christakis, D. A., \& Moreno, M. A. (2009). Trapped in the net will internet addiction become a 2st-centure epidemic? Arch. Pediatr. Adolesc. Med., 163(10), 959-960.

Duranti, A. (1997). Linguistic anthropology. Cambridge: Cambridge University Press. 


\section{Acta Technologica Dubnicae \\ volume 5, 2015, issue 2}

Fleming, M., \& Rickwood, D. (2004). Teens in cyberspace. Youth Studies Australia, 23(3).

Greenfield, P. M., \& Subrahmanyam, K. (2003). Online discourse in a teen chat room: New codes and new modes of coherence in a visual medium. Journal of Applied Developmental Psychology, 23, 713-738.

Greenfield, P., \& Yan, Z. (2006). Children, adolescents, and the Internet: a new field of inquiry in developmental psychology. Developmental Psychology, 42(3), 391-394.

Gross, E. F. (2004). Adolescent Internet use: What we expect, what teens report: New codes and new modes of coherence in visual medium. Journal of Applied Developmental Psychology, 25, 633-649.

Ito, M., Horst, H., \& Bittani, M. (2008). Living and learning with new media: Summary of findings from the digital youth project. In D. John, \& T. Catherine MacArthur Foundation Reports on Digital Media and Learning, Chicago.

Jusczyk, S. (2013). Media społeczne w procesie komunikacji i edukacji - dialog i konektywizm. In M. Wawrzaka-Chodaczek, J. Kowal, \& H. Żeligowski (Eds.), Społeczne i kulturowe wymiary komunikacji (pp. 9-22). Wrocław: Wydawnictwo Wyższej Szkoły Zarządzania „Edukacja”.

Juszczyk, S. (2014). Ethnography of virtual phenomena and processes on the Internet. The New Educational Review, 36(2), 206-216.

Lenhart, A. (2009). Teens and Sexting, Washington, DC: Pew Research Center.

Lenhart, A., Rainie L., \& Lewis, O. (2001). Teenage life online: The rise of the instant - message generation and the internet's impact on friendships and family relationships. Washington D.C.: Pew Internet and American Life Project.

Littlefield, L. (2004). Psychosocial aspects of mobile phone use among adolescents. Melbourne: The Australian Psychological Society.

Mesch, G. S. (2009). The Internet and youth culture. The Hedgenog Review, Spring.

O'Keeffe, G. S., \& Clarke-Pearson, K. (2011, April 28). Clinical report on the impact of social media on children, adolescents, and families. Pediatrics.

Olsen, S. (2006). Keeping kids safe on social sites. Retrieved from http://ww.cnet.com/news/

Patchin, J. W., \& Hinduja, S. (2006). Bullies move beyond the schoolyard: a preliminary look at cyber-bullying. Youth Violence Juv Justice, 4(2), 148169.

Selfhoud, M. H. W., Branje, S. J. T., Delsing, M., ter Bogt, T. F. M., \& Meeu, W. H. J. (2009). Different types of Internet use, depression, and social anxiety: the role of perceived friendship quality. J. Adolecents, 32(4), 819833.

Subrahmanyam, K., Kraut, R., Greenfield, P. M., \& Gross, E. F. (2001). New forms of electronic media: The impact of interactive games and the internet 


\section{Acta Technologica Dubnicae \\ volume 5, 2015, issue 2}

on cognition, socialisation, and behaviour. In D. L. Singer, J. L. Singer (Eds.), Handbook of Children and the Media (pp. 73-99), Thousand Oaks, CA: Sage.

Subrahmanyam, K., Kraut, R., Greenfield, P. M., \& Gross, E. F. (2000). The impact of home computer use on children's activities and development. Future of Children, 10, 123-144.

Wakefield, M. A., \& Rice, C. J. (2008). The impact of cyber-communication on today's youth. American Counseling Association, Professional Counseling Digest, (ACAPCD-14).

Waligóra-Huk, A. (2012). Diagnosis of aggressive behaviours among students as a sign of pathology in the rural environment with recommendation for preventive measures. The New Educational Review, 29(3), 68-81.

Zillmann, D., \& Bryant, J. (Eds.). (2002). Media effects: Advances in theory and research ( $2^{\text {nd }}$ ed.). Mahwah, NJ: Erlbaum. 